\title{
Research on Performance of High-temperature High-density Oil-based Drilling Fluids
}

\author{
Cha Ma \\ Jiangxi Key Laboratory of Organic Chemistry, Jiangxi \\ Science and Technology Normal University \\ Nanchang 330013, P. R. China \\ e-mail: macha001@126.com
}

\author{
Long Li, Jie Zhang, Rongchao Cheng, Gang Wang \\ CNPC Drilling Research Institute \\ Beijing 100083, P. R. China
}

\author{
Zhen Zhang, Xiao Liu \\ PetroChina Tarim Oilfield Company \\ Korla 841000, P. R. China
}

\begin{abstract}
The oil-gas exploitation techniques of super-deep formations in West China are facing a great challenge. Due to the super-high temperature, high pressure, salt formation, it brings enormous challenge to drilling engineering. To meet the need of drilling operation in the super-deep formations, a new kind of high-temperature high-density oil-based drilling fluid system is developed. This oil-based drilling fluid system has excellent comprehensive properties, and it could resolve the contradiction between safety drilling of complicated deep wells and formation complexity.
\end{abstract}

Keywords-high temperature; high pressure; high density; oilbased drilling fluid; performance

\section{INTRODUCTION}

The super-deep formations in West China is characterized by high temperature hydrocarbon zone, abnormal high pressure formation, salt formation, and high collapse stress formation is widely distributed, which brings great challenge to drilling operation[1-3].

Traditionally the oil and gas wells in this area are drilled with high-density water-based mud (WBM). But when the salt formations is drilled using WBM, kicks, downhole losses and stuck pipe will be often encountered, resulting in a high pressured brine influx, so higher mud weight is needed to kill the well. This is normally followed by downhole losses and stuck pipe event [4-6]. In addition, since the mud weight required in drilling the salt formation is much higher than the mud weight required in drilling the target zones, heavy losses and stuck pipe will be caused in drilling the salt formation when the target zones is inadvertently penetrated. Moreover, the water-base drilling fluids would become unstable when they are heavily contaminated by divalent salts or brine influx.

Drilling fluid stability under high temperature and high pressure, and the mud ability to tolerate the salt contamination are two of the key factors that affect the drilling efficiency in this area. The stability of the existing WBM system under high temperature, high pressure and high salinity conditions is difficult to maintain and fluid rheology is often not controllable. It is understood that the existing WBM system is not tolerant to the brine and salt contamination [7-9].

In order to meet the requirement of drilling operation in the super-deep formations, a new kind of high-temperature high-density oil-based drilling fluid system (HDOBM) is developed. The properties of HDOBM are tested in details. The results indicate that HDOBM has excellent thermal stability, and superior filtrate reducing performance. HDOBM is recommended to drill the super-deep target zones to maintain wellbore instability under HTHP conditions.

\section{EXPERIMENT}

\section{A. Synthesis of high temperature resisting primary emulsifier}

Using aliphatic acid and polyamine compound as starting material, a new type of oleamide compound is synthesized. The amount of active groups of this compound is very low, so it has good stability at high temperature. Moreover, due to its multiple amide groups, this high temperature resisting primary emulsifier could provide enough emulsion breaking voltage. This compound could maintain modest acid value and low amine value, and it has stable performance under high temperature and high-pressure conditions.

\section{B. Synthesis of high temperature resisting auxiliary emulsifier}

Using aliphatic acid and alkylol amine as starting material, a new kind of alkanolamide compound is prepared by two-step method to reduce side reaction, and it has excellent control effect on the rheological property of high density mud. Moreover, the molecular structure of this compound has two hydroxyl groups and one amide group, so it has both emulsifying and wetting function.

\section{Basic formulation and properties of HDOBM}

Based on the development of high temperature resisting primary emulsifiers, auxiliary emulsifiers, organophilic clay, 
oil-soluble filtrate loss control additive and so on, a new kind of high-temperature high density oil-based drilling fluid (HDOBM) formulation is developed, and the rheological properties of drilling fluid formulation is tested. Its antitemperature capability is as high as above $200^{\circ} \mathrm{C}$, and its maximum density is $2.60 \mathrm{~g} / \mathrm{cm}^{3}$. The basic formulation and properties of HDOBM formulation are shown in table I and table II.

TABLE I. Basic Formulations of HDOBM

\begin{tabular}{|c|c|c|c|}
\hline Composition & I & II & III \\
\hline Diesel oil, $\mathrm{mL}$ & 219.6 & 219.6 & 212.6 \\
\hline Primary emulsifier, $\mathrm{mL}$ & 17.9 & 17.9 & 21.2 \\
\hline Auxiliary emulsifier, $\mathrm{mL}$ & 10.6 & 10.6 & 14.3 \\
\hline Fluid loss additive, g & 17.9 & 17.9 & 17.9 \\
\hline Lime, g & 14.3 & 14.3 & 14.3 \\
\hline Water, $\mathrm{mL}$ & 13.5 & 13.5 & 13.5 \\
\hline Viscosifier, g & 3.6 & 3 & 4.3 \\
\hline Lime chloride, g & 7.6 & 7.6 & 7.6 \\
\hline Wetting agent, $\mathrm{mL}$ & 2.17 & 2.17 & 2.8 \\
\hline $\begin{array}{c}\text { Rheology conditioning } \\
\text { agent, } \mathrm{mL}\end{array}$ & 1.53 & 1.53 & 1.53 \\
\hline Deflocculating agent, $\mathrm{g}$ & 1.45 & 1.45 & 3 \\
\hline Barite, g & 890 & 870 & 870 \\
\hline
\end{tabular}

TABLE II. The Properties of Basic Formulations of HDOBM

\begin{tabular}{|c|c|c|c|c|c|c|}
\hline Formulation & \multicolumn{2}{|c|}{ I } & \multicolumn{2}{c|}{ II } & \multicolumn{2}{c|}{ III } \\
\hline $\begin{array}{c}\text { Aging } \\
\text { condition }\end{array}$ & $\begin{array}{c}\text { before } \\
\text { roll }\end{array}$ & $\begin{array}{c}\text { after } \\
\text { roll }\end{array}$ & $\begin{array}{c}\text { before } \\
\text { roll }\end{array}$ & $\begin{array}{c}\text { after } \\
\text { roll }\end{array}$ & $\begin{array}{c}\text { before } \\
\text { roll }\end{array}$ & $\begin{array}{c}\text { after } \\
\text { roll }\end{array}$ \\
\hline$\rho, \mathrm{g} / \mathrm{cm}^{3}$ & 2.39 & 2.37 & 2.36 & 2.36 & 2.36 & 2.41 \\
\hline $\mathrm{AV}, \mathrm{mPa} \cdot \mathrm{s}$ & 80.5 & 81.5 & 71.5 & 69.5 & 100.5 & 91 \\
\hline $\mathrm{PV}, \mathrm{mPa} \cdot \mathrm{s}$ & 71 & 81 & 65 & 72 & 84 & 86 \\
\hline $\mathrm{YP}, \mathrm{Pa}$ & 9.5 & 0.5 & 6.5 & -3.5 & 16.5 & 5 \\
\hline$\Phi 6 / \Phi 3$ & $5.5 / 5$ & $1.5 / 1$ & $4.5 / 4$ & $1 / 0.5$ & $8.5 / 7.5$ & $2.3 / 1.5$ \\
\hline $\mathrm{GEL}, \mathrm{Pa} / \mathrm{Pa}$ & $5.5 / 8$ & $1.5 / 4$ & $5.5 / 7$ & $0.5 / 1$ & $9 / 12.5$ & $2.5 / 11$ \\
\hline $\mathrm{ES}, \mathrm{V}$ & 958 & 1006 & 902 & 982 & 2047 & 1293 \\
\hline
\end{tabular}

Compared with Formulation I and Formulation II, Formulation III has better thermal stability and rheological properties before and after rolling at $180{ }^{\circ} \mathrm{C}$. In addition, Formulation III has appropriate dynamic shear force for hole cleaning, and it has good suspension ability for barite at high temperature. As a result, Formulation III is chosen as basic formulation of HDOBM for field application.

\section{The formulation and properties of HDOBM}

Based on the laboratory tests, the on-site formulation and properties of HDOBM is recommended, as shown in Table III and Table IV. The experimental results indicate that
HDOBM system has good rheological properties and sedimentation stability at high-density condition, so it can withstand high solids loadings, and provide lower HTHP fluid-loss values at high temperature and high pressure conditions.

TABLE III. The FormULATION OF HDOBM

\begin{tabular}{|c|c|}
\hline Composition & $\begin{array}{c}\text { Concentration } \\
\left(\mathbf{g} / \mathbf{m}^{\mathbf{3}} \mathbf{)}\right.\end{array}$ \\
\hline Diesel oil, $\mathrm{mL}$ & $400-430$ \\
\hline Primary emulsifier, $\mathrm{mL}$ & $30-40$ \\
\hline Auxiliary emulsifier, $\mathrm{mL}$ & $20-30$ \\
\hline Fluid loss additive, $\mathrm{g}$ & $50-60$ \\
\hline Lime, $\mathrm{g}$ & $25-35$ \\
\hline Viscosifier, $\mathrm{g}$ & $30-45$ \\
\hline Water, $\mathrm{mL}$ & $5-15$ \\
\hline Lime chloride, $\mathrm{g}$ & $15-20$ \\
\hline Wetting agent, $\mathrm{mL}$ & $5-8$ \\
\hline $\begin{array}{c}\text { Rheology conditioning } \\
\text { agent, } \mathrm{mL}\end{array}$ & $1-3$ \\
\hline Deflocculating agent, $\mathrm{g}$ & $1-3$ \\
\hline Barite, $\mathrm{g}$ & $1900-2200$ \\
\hline
\end{tabular}

TABLE IV. The Properties of HDOBM Formulation

\begin{tabular}{|c|c|}
\hline Performance & Parameter \\
\hline Density & $1.80-2.40 \mathrm{~g} / \mathrm{cm}^{3}$ \\
\hline Oil-water ratio & $90 / 10-95 / 5$ \\
\hline Electrical stability & $>600 \mathrm{~V}$ \\
\hline Funnel viscosity & $60-85 \mathrm{~s}$ \\
\hline API fluid-loss value & $0 \mathrm{~mL}$ \\
\hline HTHP fluid-loss value & $<6.0 \mathrm{~mL}$ \\
\hline Plastic viscosity & $60-90 \mathrm{MPa} \cdot \mathrm{s}$ \\
\hline Yield value & $7-15 \mathrm{~Pa}$ \\
\hline Initial gel/final gel & $2-6 / 5-10 \mathrm{~Pa}$ \\
\hline $\mathrm{pH}$ value & $7-8$ \\
\hline
\end{tabular}

Note: The rolling condition is $180^{\circ} \mathrm{C} \times 16 \mathrm{~h}$, HTHP filtration condition is $180^{\circ} \mathrm{C} \times 3.5 \mathrm{MPa}$.

\section{Results AND Discussion}

\section{A. The evaluation of ageing resistance of $H D O B M$ formulation}

The performance parameters of HDOBM before after ${ }_{\text {rplling }}$ at $180^{\circ} \mathrm{C}$ are shown in Table V. After drilling fluid formulation is rolled after various times at high temperature, the plastic viscosity of HDOBM has increased 
only marginally, the yield value and shear force of HDOBM have change very little, and it still has good suspension performance.

Meanwhile, the emulsion-breaking voltage of drilling fluids increases gradually as the rolling time rises, so the stability of drilling fluids become better and better. As a result, HDOBM has strong ageing resistance and good rheology under high temperature.

TABLE V. The Anti-Aging Properties of HDOBM Formulation

\begin{tabular}{|c|c|c|c|c|c|c|c|}
\hline \multicolumn{2}{|c|}{$\begin{array}{c}\text { Aging } \\
\text { condition }\end{array}$} & $\begin{array}{c}\text { PV } \\
(\mathbf{m P a})\end{array}$ & $\begin{array}{c}\text { YP } \\
(\mathbf{P a})\end{array}$ & $\begin{array}{c}\text { GEL } \\
(\mathbf{P a} / \mathbf{P a})\end{array}$ & $\begin{array}{c}\text { ES } \\
(\mathbf{V})\end{array}$ & $\begin{array}{c}\mathbf{F L}_{\text {HTHP }} \\
(\mathbf{m L})\end{array}$ & Note \\
\hline \multirow{2}{*}{$\begin{array}{c}\text { before } \\
\text { roll }\end{array}$} & 72 & 3.0 & $5.5 / 6$ & 407 & 1.9 & - \\
\hline \multirow{3}{*}{$\begin{array}{c}1 \\
\text { afte } \\
\text { roll }\end{array}$} & $\begin{array}{c}1 \\
6\end{array}$ & 87 & 11.5 & $5.5 / 6.0$ & 720 & 4.3 & $\begin{array}{c}\text { no } \\
\text { hrecipitation }\end{array}$ \\
\cline { 2 - 8 } & $\begin{array}{c}2 \\
\mathrm{~h}\end{array}$ & 90 & 9.0 & $5.0 / 8.0$ & 923 & 4.1 & $\begin{array}{c}\text { no } \\
\text { precipitation }\end{array}$ \\
\cline { 2 - 8 } & $\begin{array}{c}7 \\
2\end{array}$ & 97 & 7.5 & $3.0 / 5.5$ & 1047 & 3.8 & $\begin{array}{c}\text { no } \\
\text { precipitation }\end{array}$ \\
\hline
\end{tabular}

Note: The rolling condition is $180^{\circ} \mathrm{C} \times 16 \sim 72 \mathrm{~h}$, HTHP filtration condition is $180^{\circ} \mathrm{C} \times 3.5 \mathrm{MPa}$.

\section{B. The evaluation of inhibiting properties of HDOBM. Formulation}

The rolling recovery rate of mudstone cuttings in WBM and HDOBM is shown in Table VI. The results demonstrate that the average recovery rate of cuttings in WBM is $96.6 \%$, but the average recovery rate of cuttings in HDOBM is $99.0 \%$, so HDOBM has stronger inhibiting property.

TABLE VI. The Rolling Recovery Rate of Cuttings In Various DRILLING FLUIDS

\begin{tabular}{|c|c|c|}
\hline $\begin{array}{c}\text { Drilling fluid } \\
\text { system }\end{array}$ & $\begin{array}{c}\text { The recovery rate of } \\
\text { cuttings }\end{array}$ & $\begin{array}{c}\text { The average recovery } \\
\text { rate of cuttings }\end{array}$ \\
\hline \multirow{3}{*}{ WBM } & $95.8 \%$ & \multirow{2}{*}{$96.6 \%$} \\
\cline { 2 - 2 } & $97.8 \%$ & \multirow{2}{*}{$96.6 \%$} \\
\cline { 2 - 2 } & $96.2 \%$ & \multirow{2}{*}{9} \\
\hline \multirow{3}{*}{ HDOBM } & $99.6 \%$ & \\
\cline { 2 - 2 } & $98.8 \%$ & \\
\cline { 2 - 2 } & $98.6 \%$ & \\
\hline
\end{tabular}

Note: The rolling condition is $180^{\circ} \mathrm{C} \times 16 \mathrm{~h}$.

TABLE VII. The EXPERIMENT Results of EXPANSION RATIO OF VARIOUS SAMPLES

\begin{tabular}{|c|c|c|}
\hline $\begin{array}{c}\text { Base } \\
\text { fluid } \\
\text { types }\end{array}$ & $\begin{array}{c}\text { The average expansion } \\
\text { ratio of core samples }\end{array}$ & $\begin{array}{c}\text { The average expansion } \\
\text { ratio of standard bentonite }\end{array}$ \\
\hline Water & $11.35 \%$ & $40.35 \%$ \\
\hline WBM & $6.86 \%$ & $8.73 \%$ \\
\hline HDOBM & $1.84 \%$ & $3.38 \%$ \\
\hline
\end{tabular}

The expansion ratio of various samples in various drilling fluid system is shown in Table VII. The average expansion ratio of core samples in HDOBM is only $1.84 \%$, which is much less than that in water or WBM. The average expansion ratio of standard bentonite in HDOBM is much less than that in water or WBM, too. So HDOBM system has good inhibitive ability for the dispersion and hydrate expansion of clay particles of target zones, improving the wellbore stability.

\section{The evaluation of anti-pollution ability of HDOBM. formulation}

The HDOBM formulation with the oil-water ratio of 90:10 is contaminated by $10 \% \mathrm{CaSO}_{4}$ and $10 \% \mathrm{NaCl}$, respectively, and the properties of mud is tested, as shown in Table VIII.

When HDOBM formulation is contaminated by $10 \%$ $\mathrm{CaSO}_{4}$ and rolled after $16 \mathrm{~h}$ at $180{ }^{\circ} \mathrm{C}$, the viscosity of mud increases only marginally, and the yield value of mud decreases slightly, but the emulsion breaking voltage of mud increases slightly. As HDOBM formulation is contaminated by $10 \% \mathrm{NaCl}$, the rheological characteristics of mud before and after rolling change very little, but the emulsion breaking voltage of mud reduces slightly. As a result, the rheological properties of HDOBM have not changed very much after $\mathrm{CaSO}_{4}$ or $\mathrm{NaCl}$ is added to mud, so HDOBM has good antigypsum and anti-salt ability.

TABLE VIII. The ANTI-GYPSUM AND ANTI-SALt of HDOBM FORMULATION

\begin{tabular}{|c|c|c|c|c|c|}
\hline $\begin{array}{c}\text { Aging } \\
\text { condition }\end{array}$ & $\begin{array}{c}\text { PV } \\
(\mathbf{m P a} \text {.s })\end{array}$ & $\begin{array}{c}\text { YP } \\
\mathbf{( P a})\end{array}$ & $\begin{array}{c}\text { GEL } \\
(\mathbf{P a} / \mathbf{P a})\end{array}$ & $\begin{array}{c}\text { ES } \\
\mathbf{( V )}\end{array}$ & $\begin{array}{c}\text { FL } \\
\text { (mL) }\end{array}$ \\
\hline before roll & 72 & 3.0 & $5.5 / 6$ & 407 & 1.9 \\
\hline after roll & 87 & 11.5 & $5.5 / 6.0$ & 720 & 4.3 \\
\hline $10 \% \mathrm{CaSO}_{4}$ & 112 & 7 & $4.5 / 5$ & 853 & 1.2 \\
\hline $10 \% \mathrm{NaCl}$ & 102 & 6.5 & $4 / 4.5$ & 630 & 3.4 \\
\hline
\end{tabular}

The HDOBM formulation with the oil-water ratio of 90:10 is added by different proportions of saturated brines, and the anti-saturated brine properties of HDOBM formulation is tested, as shown in Table IX. The experimental results show that HDOBM formulation has stable performance when the dosage of saturated brine is less than $10 \%$. However, when the dosage is more than $15 \%$, the emulsion breaking voltage of mud before rolling can reduce remarkably, and the mud thickening becomes very serious after rolling at high temperature. 
TABLE IX. The Anti-SAturated Brine AbILITy of HDOBM Formulation with A Density of $2.50 \mathrm{G} / \mathrm{CM}^{3}$

\begin{tabular}{|c|c|c|c|c|c|c|}
\hline \multicolumn{2}{|c|}{$\begin{array}{c}\text { NaCl } \\
(\mathbf{V} / \mathbf{V} \%)\end{array}$} & $\begin{array}{c}\text { AV } \\
(\mathbf{m P a} . \mathbf{s})\end{array}$ & $\begin{array}{c}\text { PV } \\
(\mathbf{m P a} . \mathbf{s})\end{array}$ & $\begin{array}{c}\text { YP } \\
(\mathbf{P a})\end{array}$ & $\begin{array}{c}\text { GEL } \\
(\mathbf{P a} / \mathbf{P a})\end{array}$ & $\begin{array}{c}\text { ES } \\
(\mathbf{V})\end{array}$ \\
\hline \multirow{2}{*}{0} & before roll & 102.5 & 88 & 14.5 & $6.5 / 7.5$ & 2000 \\
\cline { 2 - 7 } & after roll & 106 & 95 & 11 & $6 / 6.5$ & 1300 \\
\hline $\begin{array}{c}5 \%(17.5 \\
\mathrm{mL} / 350 \\
\mathrm{~mL})\end{array}$ & before roll & 116.5 & 95 & 21.5 & $10 / 11$ & 1202 \\
\cline { 2 - 7 } & after roll & 140.5 & 117 & 23.5 & $11 / 12.5$ & 1500 \\
\hline $\begin{array}{c}10 \%(35 \\
\mathrm{mL} / 350 \\
\mathrm{~mL})\end{array}$ & before roll & 137.5 & 102 & 35.5 & $16.5 / 18$ & 1206 \\
\cline { 2 - 7 } & after roll & 156 & 130 & 26 & $20 / 21.5$ & 750 \\
\hline $\begin{array}{c}15 \%(52.5 \\
\mathrm{mL} / 350 \\
\mathrm{~mL})\end{array}$ & before roll & 133 & 92 & 41 & $19 / 21$ & 1020 \\
\cline { 2 - 7 } & after roll & $/$ & $/$ & $/$ & $20 / 26$ & 790 \\
\hline \multicolumn{2}{|c|}{} & & \multicolumn{3}{c}{ Note: The rolling condition is $180^{\circ} \mathrm{C} \times 16}$. \\
\hline
\end{tabular}

\section{CONCLUSIONS}

1) HDOBM has good rheological properties, good filtrate control capacity, strong anti-aging properties and anti-pollution ability under high temperature and high pressure conditions.

2) HDOBM can withstand high solids loadings, and provide lower HTHP fluid-loss values at high temperature and high pressure conditions.

3) HDOBM is a type of oil-based drilling fluids with superior comprehensive properties, and it can meet the need of drilling technology of super-deep formations in West China.

\section{ACKNOWLEDGMENT}

This study is supported by the National High Technology Research and Development Program of China (863 Program) (No. 2012AA091502) and CNPC Project (No. 2013E-3802).

\section{REFERENCES}

[1] H. A. Nasr-El-Din, M. B. I. Al-Otaib, and T. A. A.Al-Qah, "An effective fluid formulation to remove drilling fluid mud cake in horizontal and multi-lateral wells," SPE Drilling \& Completion, vol. 22, Dec. 2001, pp. 26-32.

[2] L. Li, X. G. Xu, J. S. Sun, et al, "Vital role of nanomaterials in drilling fluid and reservoir protection applications," Number IPTC 16,401, Nov. 2012.

[3] L. Li, X. B. Yuan, J. S. Sun, et al, "Vital role of nanotechnology and nanomaterials in the field of oilfield chemistry," Number IPTC 17,801, Mar. 2013.

[4] P. B. Dorn, D. C. L. Wong, and I. A. Rhodes, "Assessment of the fate and ecological risk of synthetic paraffin based drilling mud discharges offshore sarawak and sabah (Malaysia)," SPE 108,653, Nov. 2007.

[5] K. W. Oyler, K. J. Burrows, and G. C. West, "Diesel oil-based invert emulsion drilling fluids and methods of drilling boreholes," US Patent 7,696,131, 2010.

[6] D. Messler, D. Kippie, and T. Webb. "Improved techniques of deepwater SBM displacements: A case history," SPE 73,711, Aug. 2002

[7] J. M. Neff, A.D. Hart, J.P. Ray, et al, "An assessment of seabed impacts of synthetic-based drilling-mud cuttings in the Gulf of Mexico," SPE 94,086, Mar. 2005.

[8] N. Nabhani, M. Emami, and T. A. B. Moghadam, "Application of nanotechnology and nanomaterials in oil and gas industry," AIP Conference Proceedings, vol. 1415, Jun. 2011, pp. 128-131.

[9] D. Yin, S. J. Peng, G. Q. Liu, et al, "Innovative non-aqueous fluids technology improves drilling efficiency significantly in dealing with divalent complex gypsum-salt formation under HTHP conditions," IPTC 17,801, Dec. 2014 